\title{
Forest-savanna-morichal dynamics in relation to fire and human occupation in the southern Gran Sabana (SE Venezuela) during the last millennia
}

\author{
Encarni Montoya a,b, Valentí Rull a, Nathan D. Stansell c, Mark B. Abbott d, Sandra Nogué a,e, \\ Broxton W. Bird c, Wilmer A. Díaz f \\ a Palynology and Palaeoecology Lab, Botanical Institute of Barcelona (CSIC-ICUB), Passeig del Migdia \\ $s / n, 08038$ Barcelona, Spain \\ b Dep. of Animal Biology, Plant Biology and Ecology, Autonomous University of Barcelona, Campus \\ Bellaterra, 08193 Barcelona, Spain \\ c Byrd Polar Research Center, The Ohio State University, Scott Hall Room 108, 1090 Carmack Road, \\ Columbus, OH 43210, USA \\ d Department of Geology and Planetary Science, University of Pittsburgh, Pittsburgh, PA 15260, USA \\ e Long Term Ecology Lab. Department of Zoology, South Parks Road, OX1 3PS, UK \\ f CIEG-UNEG, Puerto Ordaz, Estado Bolivar, Venezuela
}

\begin{abstract}
The southern Gran Sabana (SE Venezuela) holds a particular type of neotropical savanna characterized by the local occurrence of morichales (Mauritia palmswamps), in a climate apparentlymore suitable for rain forests. We present a paleoecological analysis of the last millennia of Lake Chonita $\left(4^{\circ} 39^{\prime} \mathrm{N}-61^{\circ} 0^{\prime} \mathrm{W}, 884 \mathrm{~m}\right.$ elevation), based on biological and physico-chemical proxies. Savannas dominated the region during the last millennia, but a significant vegetation replacement occurred in recent times. The site was covered by a treeless savanna with nearby rainforests from 3640 to 2180 cal yr BP. Water levels were higher than today until about 2800 cal yr BP. Forests retreated since about 2180 cal yr BP onwards, likely influenced by a higher fire incidence that facilitated a dramatic expansion of morichales. The simultaneous appearance of charcoal particles and Mauritia pollen around $2000 \mathrm{cal}$ yr BP supports the potential pyrophilous nature of this palm and the importance of fire for its recent expansion. The whole picture suggests human settlements similar to today - in which fire is an essential element - since around $2000 \mathrm{yr}$ ago. Therefore, present-day southern Gran Sabana landscapes seem to have been the result of the synergy between biogeographical, climatic and anthropogenic factors, mostly fire.
\end{abstract}

\section{Keywords:}

Fire, Gran Sabana, Human occupation, Last millennia, Charcoal, Mauritia, Neotropics, Paleoecology, Vegetation change

Post-print accepted by Elsevier 5 April 2011

\section{Introduction}

Savannas are among the most important vegetation formations of the American tropics (Huber, 1987). Palynological studies show that neotropical savannas have been common during the Holocene, especially in the lowlands (e.g. Wymstra and van der Hammen, 1966; Behling and Hooghiemstra, 2001), and emphasize the importance of the lastmillennia for the shaping of present savanna landscapes (Rull, 1992; Behling 
and Hooghiemstra, 1998; Rull, 1999). In northern South America, neotropical savannas are mainly shared between Colombia (Llanos Orientales) and Venezuela (Orinoco Llanos). In addition, there is another relatively large savanna extension between Venezuela, Brazil and Guyana, which in Venezuela is called the Gran Sabana (Huber, 1995b), lying on a mid-altitude plateau, where the present study is located (Fig. 1).

Although there are several high-resolution paleoecological and paleoclimatic studies of the last millennia in Venezuela (e.g. Rull et al., 2010a), records of this type are scarce in the Gran Sabana (GS). Previous paleoecological studies reveal that during the Late Glacial and Holocene, the southern GS experienced several climatic and vegetation changes. For example, a pronounced and relatively rapid vegetation shift occurred during the Younger Dryas, which ended with the establishment of treeless savanna. This coincided with variations in the hydrological balance (precipitation/evaporation ratio) and possibly with temperature (Montoya et al., 2011). The Mapaurí record (Fig. 1), showed a dramatic change from cloud forests to savannas at the beginning of the Holocene, also linked to temperature and moisture changes (Rull, 2007). In both cases, fire seems to have played a potentially important role in the vegetation change. Two other middle Holocene records from the Divina Pastora (DV) and Santa Teresa (ST) localities show that, during the last five thousand years, the landscape was dominated by treeless savannas. However, forests were located close to these sites and/or expanded their range between 5400 and $4100 \mathrm{cal} \mathrm{yr} \mathrm{BP}$ in DV, and 5100 to $3900 \mathrm{cal} \mathrm{yr}$ BP in ST. After this time, the climate became drier and the forest extension decreased in size (Rull, 1992). Wetter conditions returned by 2700 cal yr BP, which resulted in the establishment of modern morichales (palm swamps dominated by the palm Mauritia flexuosa), rather than the expansion of forests. Similar results were obtained in the Encantada pollen record, with the initiation of morichal around 1200 cal yr BP (Montoya et al., 2009). In a nearby site called Urué (Fig. 1), the vegetation trends during the last two millennia could be reconstructed in more detail. At the beginning of this period, around $1700 \mathrm{cal} \mathrm{yr} \mathrm{BP}$, several recurrent forest fire events triggered a secondary succession that determined a significant forest reduction and the expansion of savannas, as well as the establishment of morichales (Rull, 1999). This study highlighted the effect that fires had upon Gran Sabana vegetation and the low resilience of its forests. Based on the available evidence, it could be assumed that both climatic oscillations and fire have had similar effects over the GS vegetation, that is, the reduction of forest cover and the expansion of savannas, with the establishment of morichales, thus shaping the nowadays southern GS landscape (Rull, 1992). According to Rull (1998b), the morichales, a unique neotropical vegetation type strongly linked to poorly drained and seasonally flooded soils at altitudes below around $1000 \mathrm{~m}$, would have been expanding their range since the Last Glacial Maximum, favored by both climate and fire. Montoya et al. (2009) hypothesize that M. flexuosa would be considered a pyrophilous element, as it seems an active colonizer of river margins where gallery forests have been removed by fire.

In this paper, we report the paleoecological study of a lake sediment core from Lake Chonita, in the southern GS, based on pollen and spore analysis, as well as charcoal and non-pollen palynomorphs (NPP), and some physico-chemical measurements (magnetic susceptibility, bulk density and organic matter concentration). The aim is to reconstruct the vegetation changes that occurred during the last three millennia, to analyze the savanna/morichal dynamics and the shaping of present-day southern GS landscapes, as well as to discuss the potential paleoclimatic and/or anthropogenic forcings involved, with emphasis on human occupation timing and fire regimes. The implications of these results for Mauritia biogeography, in a regional northern South America context, are also discussed. 


\section{Study area}

The GS is a vast region of about $18,000 \mathrm{~km} 2$ located in SE Venezuela $\left(4^{\circ} 36^{\prime}\right.$ to $6^{\circ} 37^{\prime} \mathrm{N}$ and $61^{\circ} 4^{\prime}$ to $74^{\circ} 2^{\prime} \mathrm{W}$, Fig. 1). The GS is part of an undulated erosion surface developed on the Precambrian Roraima quartzites and sandstones, and forms an altiplano slightly inclined to the south, ranging from about 1450 to 750 melevation in a North-south gradient (Briceño and Schubert, 1990; Huber, 1995a). The climate has been described as submesothermic ombrophilous, with annual average temperatures of around 18 to $22^{\circ} \mathrm{C}$ and precipitation values of $1600-2000 \mathrm{~mm} \mathrm{yr}-1$, with a dry season (b60 $\mathrm{mm} / \mathrm{month}$ ) from December to March (Huber and Febres, 2000). Concerning vegetation, the GS is a huge island of savanna within the normally forested Guayana landscape. These savannas form wide and more-or-less continuous treeless grasslands, locally intermingled with forests developing typical forest-savanna mosaics (Huber, 1994). The dominance of savanna vegetation in a climate apparently more suitable for the development of extensive rain forests (Huber, 1995a,b), as is the norm in surrounding regions, has lead to several hypotheses related to edaphic conditions, climate changes, and anthropogenic fires (Eden, 1974; Fölster, 1986; Rull, 1999; Fölster et al., 2001; Dezzeo et al., 2004; Huber, 2006).

However, vegetation is not homogeneous throughout the region. The occurrence of shrub and forest patches is more common in northern GS, whereas in the southern region, where our study is located, the savannas are more extensive and the forests are mostly restricted to water courses or mountain slopes. The GS savannas are dominated by $\mathrm{C} 4$ grasses of the genera Axonopus and Trachypogon, with sedges such as Bulbostylis and Rhyncospora; woody elements are scarce and rarely emerge above the herb layer (Huber, 1995b). According to Huber (1994), there is a special type of vegetation (locally called morichal) where the herbaceous stratum remains ecologically dominant (treeless savanna), but the palm $M$. flexuosa forms characteristic monospecific stands. This vegetation type is especially common around lakes, and in the bottom of river valleys and flooded depressions of the southern GS, up to about 1000 m elevation (Huber, 1995b). The morichales are absent in northern GS due to this altitudinal limit. There is a general lack of knowledge about this palm species' biology and the communities it forms in the Gran Sabana (Ponce et al., 1999). Most GS forests are considered to fall within the category of lower montane forests (also called submesothermic forests, between 800 and $1500 \mathrm{~m}$ elevation), because of their intermediate position between lowland and highland forests (Hernández, 1999). Common genera include: Virola (Myristicaceae), Protium (Burseraceae), Tabebuia (Bignoniaceae), Ruizterania (Vochysiaceae), Licania (Chrysobalanaceae), Clathrotropis (Fabaceae), Aspidosperma (Apocynaceae), Caraipa (Clusiaceae), Dimorphandra (Caesalpiniaceae), Byrsonima (Malpighiaceae), etc., and their composition varies with elevation (Huber, 1995b). The GS shrublands usually occur between 800 and $1500 \mathrm{~m}$ elevation and are more frequent at the northern area than at the southern part (Huber, 1995b), where our study site is located. Themore common shrub genera are: Euphronia (Euphroniaceae), Bonyunia (Loganiaceae), Bonnetia and Ternstroemia (Theaceae), Clusia (Clusiaceae), Gongylolepis (Asteraceae), Macairea (Melastomataceae), Humiria and Vantanea (Humiriaceae), Ochthocosmus and Cyrillopsis (Ixonanthaceae), Thibaudia, Notopora and Befaria (Ericaceae), Spathelia (Rutaceae), Byrsonima (Malpighiaceae), etc. They usually grow on a rocky, sandstone substrate or deep white sands of alluvial origin (Huber, 1995b). 
The GS region is the homeland of the Pemón indigenous group, from the Caribspeaking family. Today they are sedentary, living in small villages, usually in open savannas. Though the GS population density is currently low, the indigenous settlements have experienced an expansion since the arrival of European missions, and today, more than 17,000 people live in the GS (Medina et al., 2004). Fire is a key component of the Pemón culture as they use it every day to burn wide extensions of savannas, and occasionally, forests (Kingsbury, 2001). The reasons for the extent and frequency of these fires are related to activities such as cooking, hunting, fire prevention, communication, magic, etc. (Rodríguez, 2004, 2007). Surprisingly, land-use practices, such as extensive agriculture or cattle raising, typical of other cultures strongly linked to fire, are not characteristic of the Pemón culture (Rodríguez, 2004). The arrival timing of Pemón culture to the GS remains unknown. A recent settlement in the region during the last centuries has been assumed, migrating from Guyana or northern Brazil (Huber, 1995a; Kingsbury, 1999) but thiswould be constrained by the availability of historical accounts that do not necessarily record the first occupation event (Thomas, 1982; Colson, 1985). Therefore, an early occupation should not be dismissed. There is some archeological evidence consisting of pre-Hispanic remains (spearheads and bifacial worked knives) similar in style to others that are about $9000 \mathrm{yr}$ old found in other Venezuelan localities (Gassón, 2002; Rostain, 2008). In addition, palynological evidence indicating the occurrence of intense and extensive fires during the Younger Dryas (around 12,400 cal yr BP), suggested a potential early human occupation of the GS as one of the potential factors for fire occurrence (Montoya et al., 2011), but a definitive assessment is not yet possible.

\section{Materials and methods}

Lake Chonita $\left(4^{\circ} 39^{\prime} \mathrm{N}-61^{\circ} 0^{\prime} \mathrm{W}, 884 \mathrm{~m}\right.$ elevation) is located within a private farm called "Hato Divina Pastora" near Santa Elena de Uairén, at the south of the GS region (Fig. 1). The annual precipitation in Santa Elena, at $910 \mathrm{~m}$ altitude, is about $1700 \mathrm{~mm}$, with a weak dry season from December to March (Huber, 1995a). The lake is within a treeless savanna landscape, surrounded by scattered morichal patches. In the absence of a known local name for the lake, it will be called Lake Chonita for the purposes of the present study, to be consistent with previous studies developed at the same site (Montoya et al., 2011). The core (PATAM1 B07; 4.67 mlong) was obtained in the deepest part of the lake (3.13 m water depth), using a modified Livingstone squared-rod piston core (Wright et al., 1984). The present study is focused on the detailed analysis, and paleoecological interpretation, of the last three millennia interval $(0.03$ to $0.97 \mathrm{~m})$. A total of nine samples were taken along the whole core for radiocarbon dating, three of them falling within the interval discussed here. Samples were pretreated using standard acid-base-acid procedures (Abbott and Stafford, 1996) and measured at the AMS Radiocarbon Laboratory of the University of California, Irvine (UCI) and Beta Analytic (Beta). Calibration was made using CALIB 6.0.1 and the IntCal09.14c database (http://calib.qub.ac.uk./calib/, last accessed on April 2010).

Twenty-eight volumetric samples $(2 \mathrm{~cm} 3)$ were taken in the section studied, at 2-5 cm intervals, for pollen analysis. These samples were processed using standard palynological techniques slightly modified according to the sediment nature (Rull et al., 2010b), after spiking with Lycopodium tablets (batch 177745, average 18,584 \pm 1853 spores/tablet). The slides were mounted in silicone oil without sealing. Pollen and spore identification was made according to Hooghiemstra (1984), Roubik and Moreno (1991), Tryon and Lugardon (1991), Herrera and Urrego (1996), Rull (1998a, 2003) and Colinvaux et al. (1999). Counts were conducted until a minimum of 300 pollen and spores were tabulated (excluding Cyperaceae and aquatic plants: Myriophyllum, 
Sagittaria and Utricularia), but counting continued until the saturation of diversitywas reached (Rull, 1987). Final counts averaged 533 grains per sample. Pollen taxa were grouped according to the vegetation types previously described (Huber, 1986, 1989, 1994, 1995b; Huber and Febres, 2000). All identified pollen taxa were included into the pollen sum, except for Cyperaceae and the aquatic plants mentioned above. Pollen diagrams were plotted with PSIMPOLL 4.26, using a time scale derived from an agedepth model based on radiocarbon dating, developed with the clam.R statistical package (Blaauw, 2010). The pollen zonation was performed by Optimal Splitting by Information Content (OSIC), and the number of significant zoneswas determined by the broken-stickmodel test (Bennett, 1996). Only pollen types over $0.4 \%$ were considered for zonation. Interpretation was based on comparison with modern samples fromprevious studies (Rull, 1992, 1999) and the known autoecology of taxa found (Marchant et al., 2002; Rull, 2003). Sample PATAM1_B07/8, $38 \mathrm{~cm}$ depth was excluded due to methodological problems. NPP were analyzed on pollen slides, and plotted in percentages based on pollen sum. NPP identification was made according to Montoya et al. (2010) and literature therein. Charcoal counts were carried out in the same pollen slides, considering two size classes (Rull, 1999):

- Type I (smaller microcharcoal particles: 5-100 $\mu \mathrm{m}$ ): used as proxy for mostly regional fires, because of their easy dispersion by wind.

- Type II: (larger microcharcoal particles: N100 $\mu \mathrm{m}$ ): used as proxy for local fires.

Bulk density (BD) was measured on $1 \mathrm{~cm} 3$ samples, taken every $5 \mathrm{~cm}$ down-core. The samples were weighed wet, and again after drying in a $60^{\circ} \mathrm{C}$ oven for $24 \mathrm{~h}$. Total organic matter was measured every $5 \mathrm{~cm}$ by loss-on-ignition (LOI) at $550^{\circ} \mathrm{C}$ (Dean, 1974). There is no measurable calcium carbonate in the sediments, based on LOI measurements made after burning at $1000^{\circ} \mathrm{C}$. Magnetic susceptibility (MS) was measured at a $0.5 \mathrm{~cm}$ interval using a Tamiscan highresolution surface scanning sensor connected to a Bartington susceptibility meter at the University of Pittsburgh.

\section{Results}

\section{Lithology and chronology}

The lacustrine sequence is characterized, in the studied section, by dark-brown organic-rich sediments. The upper part of the section is characterized by slightly higher magnetic susceptibility values than the lower one, with a major peak between $\sim 30$ and $24 \mathrm{~cm}$ and a minor peak in the upper $10 \mathrm{~cm}$ (between 8.5 and $1.5 \mathrm{~cm}$ ). The organic matter data shows changes in the relative amounts of organic matter and terrigenous (mineral) sediments in the core (Fig. 2). Generally, sections with high dry bulk density (Fig. 2) also have lower organic matter and high in terrigenous sediments. Dry BD shows a high variability and presents its maximum values between $\sim 30$ and $24 \mathrm{~cm}$, coinciding with the major MS peak. Organic matter is characterized by a fluctuating trend followed by an abrupt increase in the upper $20-10 \mathrm{~cm}$ of the record.

The results of AMS radiocarbon dating were used to produce an age-depth model for the sequence (Table 1). The best fit was obtained with a smooth-spline function (Blaauw, 2010), and is represented in Figure 2 only for the interval of interest of this study. The sedimentation rate of the whole sequence varies between 0.02 and $0.17 \mathrm{~cm}$ $\mathrm{yr}-1$. For the interval studied here, the sedimentation rate ranges between 0.02 and $0.08 \mathrm{~cm} \mathrm{yr}-1$. The time interval between samples ranges from 60 to $150 \mathrm{yr}$. 


\section{Palynological zonation}

The pollen diagram is dominated by pollen assemblages from two different herbaceous plant formations: a treeless savanna, with a nearby forest in the lower part; and a savanna with morichal, coinciding with a decrease in forest elements, in the upper half (Figs. $\underline{3}$ and $\underline{5}$ ). The pteridophyte spores are not very abundant, though psilate triletes and monoletes are better represented than others. Regarding NPP, Botryococcus, Coniochaeta cf. ligniaria and Neorhabdocoela oocites are the more abundant (Fig. 4). The stratigraphic variations of the pollen and spore assemblages allowed subdivision of the diagram into two zones.

\section{LCH-I (97-37 cm, 14 samples)}

The pollen assemblage is clearly dominated by Poaceae, which presents fluctuating values ranging from 40 to $70 \%$ of the total pollen sum, followed by trees (mainly Urticales) (Fig. 3). Some forest elements are also present at high to medium abundances, as for example Urticales (the more abundant of them), Alchornea, Byrsonima, Cecropia, Euphorbiaceae-type, Miconia, Myrsine and Weinmannia. Mauritia appears at the top of the zone, though with low abundance. The percentages of pteridophyte spores are low, but a slight increasing trend can be observed in psilate monoletes and psilate triletes at the top of the zone. Smaller charcoal particles (5-100 $\mu \mathrm{m})$ remain at low abundances, with an increase at the top of the zone, coinciding with the first appearance of larger particles (N100 $\mu \mathrm{m})$. Regarding influx index, it can be observed that Urticales, show relatively stable values, with a slight decrease at the top of the zone (Fig. 5). Figure 5 also shows an increasing trend of Mauritia and charcoal particles towards the top. Among aquatic elements (algal remains and aquatic or semiaquatic plants; Fig. 4), Botryococcus is the dominant, with strong fluctuations in its concentration and a sharp decrease in the upper part of the zone. Type 91 (HdV. 91) shows an increase at the upper part of the zone, and Spirogyra peaks at the top. Cyperaceae are also abundant, with minor variations, and Sagittaria shows a slightly decreasing trend at the upper part of the zone. Regarding fungal spores and other NPP, the more abundant are Coniochaeta cf. ligniaria, Neorhabdocoela oocites, Cercophora-type and Sordaria-type, thought Sordariales also presents a peak at the lower part of the zone (Fig. 4).

\section{LCH-II (37-3 cm, 14 samples)}

The pollen assemblage is marked by an abrupt increase of Mauritia likely at the expense of trees, in the lower half of the zone, and of trees and Poaceae in the upper part, from around $35 \mathrm{~cm}$ upwards (Fig. 3 ). There is a decrease of Mauritia and a return to the former higher values of Poaceae in the intermediate part of the zone $(32-18 \mathrm{~cm})$. Above this depth, Mauritia increases again synchronously with a decrease in Poaceae. There is a general decreasing trend of nearly all the forest elements, which in some taxa, as Alchornea and Bonyunia-type, represent almost their complete disappearance. Pteridophyte spores remain at similarly low values to the previous zone. Psilate triletes has higher values at the base of the zone, showing a slightly decreasing trend from $\sim 30 \mathrm{~cm}$ upwards. Smaller charcoal particles maintain the increasing trend initiated at the upper part of the previous zone, and experience three abrupt peaks, the first one around 32 to $23 \mathrm{~cm}$, and the other two, of higher magnitude, at 18 and $8 \mathrm{~cm}$, respectively (Fig. 3). Larger charcoal particles remain low at the beginning of the section, and show a pattern similar to smaller particles, but significantly lower in magnitude, throughout the zone. All the biological proxies analyzed show an increase in their influx indices, except for pteridophyte spores (Fig. 3). Figure 5 shows higher 
values of Mauritia pollen and charcoal particles and lower values of Urticales with respect to the former zone. Aquatic elements and fungal spores and other NPP are characterized by lower abundances respect to the former zone, except for Cyperaceae, which shows similar values (Fig. 4). The correlation between Mauritia and total charcoal influx index curves (Fig. 5) was performed, obtaining an $R$ value of 0.718 , which is significant for ab0.001.

\section{Discussion}

The region around Lake Chonita has remained a savanna during the last threemillennia, but a significant vegetation change occurred around $2000 \mathrm{yr}$ ago. Indeed, prior to 2180 cal yr BP, a treeless savanna landscape with nearby forests dominated the site, but the last two millennia have been characterized by forest retraction and the establishment of a morichal, which remains until present. The paleoecological sequence is discussed in the following sections in the context of northern South American savannas, and the contribution of these results to the understanding of the fire-vegetation relationships at South GS.

\section{Paleoecological interpretation}

\section{0 to $2180 \mathrm{cal}$ yr BP}

The sedimentary features and the presence of aquatic organisms indicate that the lake probablywas already established prior to $3640 \mathrm{cal} \mathrm{yr} \mathrm{BP.} \mathrm{The} \mathrm{pollen} \mathrm{assemblage} \mathrm{of} \mathrm{this}$ zone indicates a treeless savanna landscape without morichales. The abundance of forest elements suggests that this formationwas probably closer and/or more expanded than today. The continued presence of smaller charcoal particles - indicative of regional fires - together with the continuous presence of Cecropia - a secondary colonizer - may indicate some regional fires of low intensity occurred. The lack of coarse charcoal indicates local fires did not occur. The first appearance of larger microcharcoal particles, as proxies for local fires, were recorded at $\sim 2400$ cal yr BP. This occurred synchronously with the first appearance, though at low values, of Mauritia pollen, and an increase in psilate triletes. These spores have been related with early stages of secondary succession after fire, in other sites of the GS (Rull, 1999). The high values of Botryococcus and Neorhabdocoela oocites from 3640 to $2800 \mathrm{cal} \mathrm{yr}$ BP suggest that lake levels were stable. During this time period climate might have varied from a higher water balance prior to $2800 \mathrm{cal}$ yr BP to lower moisture availability from this date to the end of the interval, as indicated by the lower values of aquatic organisms, mainly Botryococcus and Neorhabdocoela. This is in agreement with the Encantada record (Montoya et al., 2009), but it does not coincide exactly with other GS records, as for example DV or ST (Rull, 1992). Dating inconsistencies in previous records derived from the use of large quantities of bulk sediment for dating using conventional radiocarbonmethods instead of AMS techniques, and the few dates available for a sound age-depth model cannot be dismissed for this time interval.

Similar trends regarding water levels and climate have been observed in some paleoecological and paleoclimatic records from northern South America. For instance, Lake Valencia (Fig. 1) had higher water levels from 6000 to $300014 \mathrm{C}$ yr BP ( 6840 to $3200 \mathrm{cal}$ yr BP), except for a short interval of lower lake levels centered at $330014 \mathrm{C} \mathrm{yr}$ BP ( 3550 cal yr BP) (Bradbury et al., 1981; Leyden, 1985; Curtis et al., 1999). From this, some of these authors inferred a high precipitation/evaporation ratio (P/E) determined by higher insolation and changes in the latitudinal position of the Intertropical Convergence Zone (ITCZ) (Curtis et al., 1999). Haug et al. (2001) inferred a decrease in precipitation from 5350 cal yr BP in the Cariaco Basin (Fig. 1), with large 
century-scale variations between $\sim 3750$ and 2750 cal yr BP. In the Colombian Llanos Orientales, a wetter interval was suggested for the middle Holocene, peaking around 4000 cal yr BP (Marchant and Hooghiemstra, 2004). Such climatic inferences were supported by evidence of forest expansion in different records (e.g. Behling and Hooghiemstra, 1998, 1999, 2000; Berrío et al., 2002). Contrarily, the Rupununi savannas of Guyana (Fig. 1), would have had a continuous presence of treeless savanna since the middle Holocene, with an increase in Poaceae around $300014 \mathrm{C} \mathrm{yr}$ BP ( 3200 cal yr BP) (Wymstra and van der Hammen, 1966). Therefore, a likely forest expansion in the present savanna areas of northern South America prior to $3000 \mathrm{cal} \mathrm{yr}$ $\mathrm{BP}$, probably linked to an increase in moisture, seems to be supported by the available evidence. The regional differences found in nearby locations could be related to local climate variations.

\section{$2180 \mathrm{cal}$ yr BP to present}

The beginning of this time interval was marked by an abrupt local vegetation change, though the general GS landscape continued to be dominated by treeless savannas. The sudden increase of Mauritia coincideswith a decrease of Poaceae and forest elements. While Poaceae abundance returned to former values at ca. $1920 \mathrm{cal} \mathrm{yr}$ BP, the forest did not show any recovery until the present. The increase in fire incidence during this interval could have been decisive in this sense, favoring the establishment of morichal communities, as suggested by several former studies (Rull, 1992, 1998b, 1999; Montoya et al., 2009). The synchrony showed in the influx index between the increment of Mauritia pollen and charcoal particles and the decline of Urticales, interpreted in this work as indicative of forest presence according to Gosling et al. (2009), agrees with this assumption (Fig. 5). The potential establishment of a drier regional climate since 2800 cal yr BP (Bradbury et al., 1981; Curtis et al., 1999; Berrío et al., 2000; Behling and Hooghiemstra, 2001; Berrío et al., 2002; Wille et al., 2003), might indicate some level of climatic influence (or a synergistic fire-climate coupling) on forest retraction. The treeless savanna expanded again from 1920 to $1120 \mathrm{cal} \mathrm{yr} \mathrm{BP}$, synchronouslywith a decrease of Mauritia abundance. At the same time, there is a major peak in MS and BD curves. Such synchrony could be interpreted as a higher input of terrigenous sediments to thewatershed due to erosion processes caused by the existence of a more open landscape resulting from Mauritia clearing. After that, two major charcoal peaks recorded at ca. 1120 and 480 cal yr BP coincide with the morichal expansion. Thus, it is suggested that the present-day landscape around Lake Chonita was established around $1120 \mathrm{cal}$ yr BP. The MS minor peak occurred this time paralleled the Mauritia increase and is dated ca. 500 to 50 cal yr BP,which is synchronouswith the Little Ice Age (LIA) recorded in the Venezuelan Andes, as a cool and humid interval linked to solar activity cycles (Polissar et al., 2006). In Lake Chonita, the only potential evidence for more humid conditions is the Mauritia increase at the top. However, aquatic elements indicate that during thewhole interval moisture conditionswere more or less stable, and similar to present-day, with minor variations, so a definitive interpretation cannot be made.

The recent appearance and sudden increase of Mauritia, or the establishment of present-day morichales, coinciding with an increased fire incidence have also been reported inmost sequences in the GS (e.g.: DV, ST, Urué and Encantada) (Rull, 1992, 1999; Montoya et al., 2009). Sudden increases of Mauritia and/or slightly drier climate than mid Holocene relative to the lastmillennia have also been reported in several studies in nearby areas. In the Venezuelan Llanos, Mauritia presence was also reported only for the last two millennia, in a climate likely more humid than the previous interval (Leal et al., 2002, 2003). In the Colombian Llanos, the same trends have been 
observed, during the last two millennia, in several localities (Behling and Hooghiemstra, 1998, 1999, 2000; Berrío et al., 2000; Behling and Hooghiemstra, 2001; Berrío et al., 2002; Wille et al., 2003). Hence, there is a general agreement regarding the influence of increased human impact, usually through fire, in the establishment of morichales, and the shaping of the present savanna landscapes during the last two millennia.

\section{Mauritia, climate, fire, and human occupation in the GS}

Several studies developed in the GS have revealed the continuous persistence of savannas since at least the early Holocene (Rull, 2007; Montoya et al., 2011). However, the taxonomic composition of this biome has shown the dynamic nature of its plant communities. This is the case of morichales, whose occurrence has been traditionally considered indicative of warm and wet lowlands (and midlands) of northern South America. As a consequence, morichal expansions observed in paleoecological records have been generally interpreted in terms of wetter climate (e.g. Rull, 1992; Behling and Hooghiemstra, 1999; Rull, 1999; Berrío et al., 2000; Leal et al., 2002, 2003). The appearance and expansion of Mauritia-dominated communities in the Colombian Llanos Orientales (Fig. 6), likely agree with this climatic interpretation. Thereby, this palmwas recorded for first time around the middle Holocene, where a wet period was documented for the region (Marchant and Hooghiemstra, 2004). In our study, however, the recent morichal expansion occurred in a climate drier than the preceding phase which, at first, seems contradictory. Nevertheless, this evidence also suggests that climate is not the only factor affecting the morichal occurrence and distribution at southern GS, which appears to be linked strongly to fire incidence or to fire-climate synergies (Fig. 5). The synchrony between increased fire frequency and morichal establishment recorded in several GS sequences together with the correlation degree obtained, as well as the common presence of charcoal particles in palynological slides, supports this view. This is in agreement with the absence of Mauritia palmswamps during the Holocene in theGS, despite the occurrence of periods of higher moisture availability, and its later expansion during phases of high fire incidence (e.g. Montoya et al., 2009). This supports the assumed pyrophilous character of Mauritia and the morichales it forms (Montoya et al., 2009), favored by humaninduced forest clearing by fire. Another potential factor involved would be geographical. According to Rull (1998b)Mauritia has been expanding its range since the end of last glaciation, so it is possible that this palmdid not reach the GS until the last two millennia. This would also help to explain its former absence in the GS during Holocene periods, with assumedly optimal ecological conditions, when it was indeed present in the Colombian Llanos Orientales (Fig. 6). Overall, this suggests that the present-day distribution of this palm could be the result of a synergism between biogeography (post-glacial expansion), climate (humid conditions) and human disturbance (fire). Unfortunately, the lack of charcoal data for most of the available neotropical records prevents a regional synthesis of the potential effect of fire upon Mauritia communities.

The existing evidence suggests that fire is a key factor to understand the GS environmental history. Asmentioned before, the GS has been the homeland of the Pemón indigenous group at least during the last $300 \mathrm{yr}$. The intensive and extensive use of fire by this culture is well documented (Kingsbury, 2001; Rodríguez, 2004, 2007), and has been often related to the current extension of savannas and forests (Dezzeo et al., 2004; Huber, 2006). The high amount of charcoal in different neotropical records has been postulated as indicative of human settlements, even in the absence of changes in land use (Bush et al., 2007). Moreover, there is some archeological evidence of human populations synchronouswith charcoal peaks around the Orinoco Basin, frequently located close to water courses (e.g.: Saldarriaga and 
Webs, 1986). The continuous presence of local fires at Lake Chonita since about 2000 yr ago (Figs. $\underline{3}$ and $\underline{5}$ ), suggests an earlier human occupation of the lake catchment. If so, one possible scenario is that once humans arrived, theymade fires for different reasons, and the forest suppression favored the morichal establishment where edaphic conditions were suitable. In this case, humidity seems to have played a minor role in the palm establishment, due to the time elapsed between the decrease in water levels and the Mauritia expansion (Figs. $\underline{3}$ and $\underline{4}$ ). The progressive soil degradation caused by the maintained fires should be also considered (Dezzeo et al., 2004). Conversely, the synchrony between increases in charcoal and Mauritia after $2000 \mathrm{yr}$ ago point to this possible early human settlement at South GS, not necessarily of the Pemón culture, but a similar culture at least in regard to the use of fire. The extensive use of palms by many indigenous cultures from the Neotropics supports this assumption (Heckenberger and Neves, 2009).

\section{Biogeographic considerations on Mauritia}

Given the results presented here, some considerations regarding morichal communities seem pertinent. Figure 6 shows the age of modern-day Mauritia community establishment in different paleoecological records from northern South American savannas. Mauritia pollen can be present both in monospecific palm formations (with percentages from 10 to $30 \%$ or more), and in mixed or gallery forests (with percentages from 1 to 4\%) (Rull, 1992). Thus, the age marks not the first appearance of Mauritia pollen in the record, but the formation of a modern morichal community. In a northern South American context, the Holocene colonization of the GS by Mauritia seems to have occurred later than in the savannas from the Orinoco lowlands (Fig. 6). This would be due in part to anthropogenic factors (i.e. time of arrival of fire-prone cultures), but the physical isolation of the GS from any other savanna patch would have also played a role. Mauritia has no long-distance dispersal by wind, and its seeds are commonly transported by animals (mousses, opossums, squirrels, agoutis, peccaries, and others) or by water (Ponce, 2002). Therefore, a physical connection is needed for Mauritia expansion. At present, there is no such connection in the GS. One possibility is that Mauritia reached the GS during a phase of a general savanna expansion, which would have caused a less fragmented pattern, but there is no any paleoecological record suggesting such a framework after around $2000 \mathrm{yr}$ ago. It is also possible that humans were the dispersal agents, as it is known that this palm is widely and intensively used by indigenous cultures for housing, food, and other relevant activities (Henderson et al., 1995; Gomez-Beloz, 2002; Heckenberger and Neves, 2009). In this case, physical connection is not mandatory, as humans could have migrated from one savanna patch to another through the rainforest. Concerning the source, colonization from the north is unlikely because the northern GS is a physical barrier due to its elevation, around 400-500 $\mathrm{m}$ higher than required for Mauritia, whose upper limit is around $1000 \mathrm{~m}$ altitude. For Mauritia to reach such elevations and cross this barrier, an increase of ca. $2.5-3.0^{\circ} \mathrm{C}$ in the annual average temperatures would be needed by $2000 \mathrm{cal}$ yr BP, but this has not been found in the GS records to date. Therefore, the GS populations of this palm species should come from elsewhere. With the presently available - though very scarce - data, the more likely source seems to be the Amazon Basin (Rull, 1998b). This should be considered a working hypothesis, which needs further palynological analysis (including charcoal records) combined with anthropological and archeological studies. Emphasis should be placed on the precise delimitation of present-day Mauritia distribution, which is still largely unknown, and the design of a coring strategy able to produce a network of sites with dated first appearances of the Mauritia pollen, in order to follow the spatio- 
temporal colonization patterns. Intraspecific phylogeographic studies would also help to reconstruct migrational patterns and potential genetic variability among populations, to help test biogeographical hypotheses based on paleoecological results.

\section{Conclusions}

The palynological study of the upper part of the lake Chonita sequence, from southern GS, allows for the reconstruction of vegetation changes during the last three millennia. Although savannas were the dominant vegetation type, two different savanna landscapes are recognized: a treeless savannawith forestsmore extensive and/or closer than today prior to 2180 cal yr BP (with likely higherwater levels prior to 2800 cal yr BP), and a savanna with morichal, under intensivefire regimes thereafter. The abrupt and dramatic increase of Mauritia, and the concomitant decrease of forest elements occurred around $2000 \mathrm{cal}$ yr BP could have been caused by fire. At the same time, a shift to drier conditions than in the mid-Holocene has been reported in nearby localities suggesting that a regional climate change should also be considered, but given the preference of Mauritia for humid climates, the hypothesis of fire is better supported. The synchronous appearance of Mauritia and charcoal, together with the disappearance of forests, support the hypothesis of a potential pyrophilous nature of this palm (Montoya et al., 2009). The continuous occurrence of local fires during the last two millennia around Lake Chonita suggests the presence of human settlements well before the assumed colonization around the last centuries. The results presented here highlight the importance of the interplay between climate and fire to explain the present-day GS vegetation. The colonization of the GS by Mauritia appears to have occurred later than in the ColombianOrinoco Llanos, probably because of a later human occupation and the physical isolation of these savanna patches with respect to the main northern South American savanna areas. Further studies are require to test this hypothesis, but it seems that the present geographical patterns of Mauritia, and the monospecific communities it forms, are the result of the synergy between biogeographic, climatic and anthropogenic factors, with human-made fires as a major cause.

\section{Appendix A}

Localities depicted in Figure 6. The different sequences are ordered chronologically, by the time of appearance Mauritia or Mauritiella palmstands or morichales, expressed as cal yr BP. Fire column refers to the coincidence between morichal pollen and charcoal increase. $\mathrm{N}$ marks those localities wheremorichaleswere already present at the beginning of the record. Elev.: Elevation (in meters); Carim: Carimagua; ND: no data; GS: Gran Sabana.

\begin{tabular}{|c|c|c|c|c|c|c|c|}
\hline $\mathbf{N}^{\circ}$ & Locality & Coordinates & Elev. & Region & Morichal & Fire & Reference \\
\hline 1 & Chenevo & $4^{\circ} 5^{\prime} \mathrm{N}-70^{\circ} 21^{\prime} \mathrm{W}$ & 150 & Colombia & 6330 & ND & Berrío et al., 2002 \\
\hline 2 & Angel & $4^{\circ} 28^{\prime} \mathrm{N}-70^{\circ} 34^{\prime} \mathrm{W}$ & 200 & Colombia & 4290 & ND & Behling \& Hooghiemstra, 1998 \\
\hline 3 & Carimagua & $4^{\circ} 4^{\prime} \mathrm{N}-70^{\circ} 14^{\prime} \mathrm{W}$ & 180 & Colombia & 4260 & ND & Behling \& Hooghiemstra, 1999 \\
\hline 4 & Sardinas & $4^{\circ} 58^{\prime} \mathrm{N}-69^{\circ} 28^{\prime} \mathrm{W}$ & 80 & Colombia & 4030 & ND & Behling \& Hooghiemstra, 1998 \\
\hline 5 & Mozambique & $3^{\circ} 58^{\prime} \mathrm{N}-73^{\circ} 3^{\prime} \mathrm{W}$ & 175 & Colombia & 3720 & ND & Berrío et al., 2002 \\
\hline 6 & Margaritas & $3^{\circ} 23^{\prime} \mathrm{N}-73^{\circ} 26^{\prime} \mathrm{W}$ & 290 & Colombia & 2500 & Yes & Wille et al., 2003 \\
\hline 7 & Loma Linda & $3^{\circ} 18^{\prime} \mathrm{N}-73^{\circ} 23^{\prime} \mathrm{W}$ & 310 & Colombia & 2330 & ND & Behling \& Hooghiemstra, 2000 \\
\hline 9 & Chonita & $4^{\circ} 39^{\prime} \mathrm{N}-61^{\circ} \mathrm{W}$ & 884 & Venezuela, GS & 2175 & Yes & This publication \\
\hline 10 & Sta. Barbara & $9^{\circ} 33^{\prime} \mathrm{N}-63^{\circ} 40^{\prime} \mathrm{W}$ & 80 & Venezuela & $>1960$ & ND & Leal et al., 2002, 2003 \\
\hline 11 & Sta. Teresa & $4^{\circ} 43^{\prime} \mathrm{N}-61^{\circ} 5^{\prime} \mathrm{W}$ & 880 & Venezuela, GS & 1700 & ND & Rull, 1992 \\
\hline 12 & Div. Pastora & $4^{\circ} 42^{\prime} \mathrm{N}-61^{\circ} 4^{\prime} \mathrm{W}$ & 800 & Venezuela, GS & 1500 & ND & Rull, 1992 \\
\hline 13 & Encantada & $4^{\circ} 42^{\prime} \mathrm{N}-61^{\circ} 4^{\prime} \mathrm{W}$ & 867 & Venezuela, GS & 1220 & Yes & Montoya et al., 2009 \\
\hline 14 & Urué & $5^{\circ} 2^{\prime} \mathrm{N}-61^{\circ} 10^{\prime} \mathrm{W}$ & 940 & Venezuela, GS & 990 & Yes & Rull, 1999 \\
\hline 15 & Carim-Bosque & $4^{\circ} 4^{\prime} \mathrm{N}-70^{\circ} 13^{\prime} \mathrm{W}$ & 180 & Colombia & $>1190,80$ & ND & Berrío et al., 2000 \\
\hline
\end{tabular}




\section{Acknowledgments}

This work was supported by Spanish Ministry of Science and Innovation (former Ministry of Education and Science), projects CGL2006-00974 and CGL200907069/BOS to V. Rull, and grant BES-2007-16308 to E. Montoya. Permits to develop the research in Venezuela were provided by the Ministry of Science and Technology (DM/0000013, 5 Jan 2007), and sampling permits were provided by the Ministry of Environment ( $n^{\circ}$ IE-085, 9 Feb 2007). Thanks to Ana $M^{a}$ Pérez, because of her huge effort to obtain them, to Fidencio Montáñez, owner of Hato Divina Pastora, for his interest and good will for our work, to Maarten Blaauw for his help with the age-depth modeling and to Iñigo de la Cerda for his support in the project. Thanks to Jose S. Carrión, for the use of his lab for pollen processing. The comments of two referees (lokiñe Rodríguez and another anonymous) contributed to the improvement of the manuscript. 


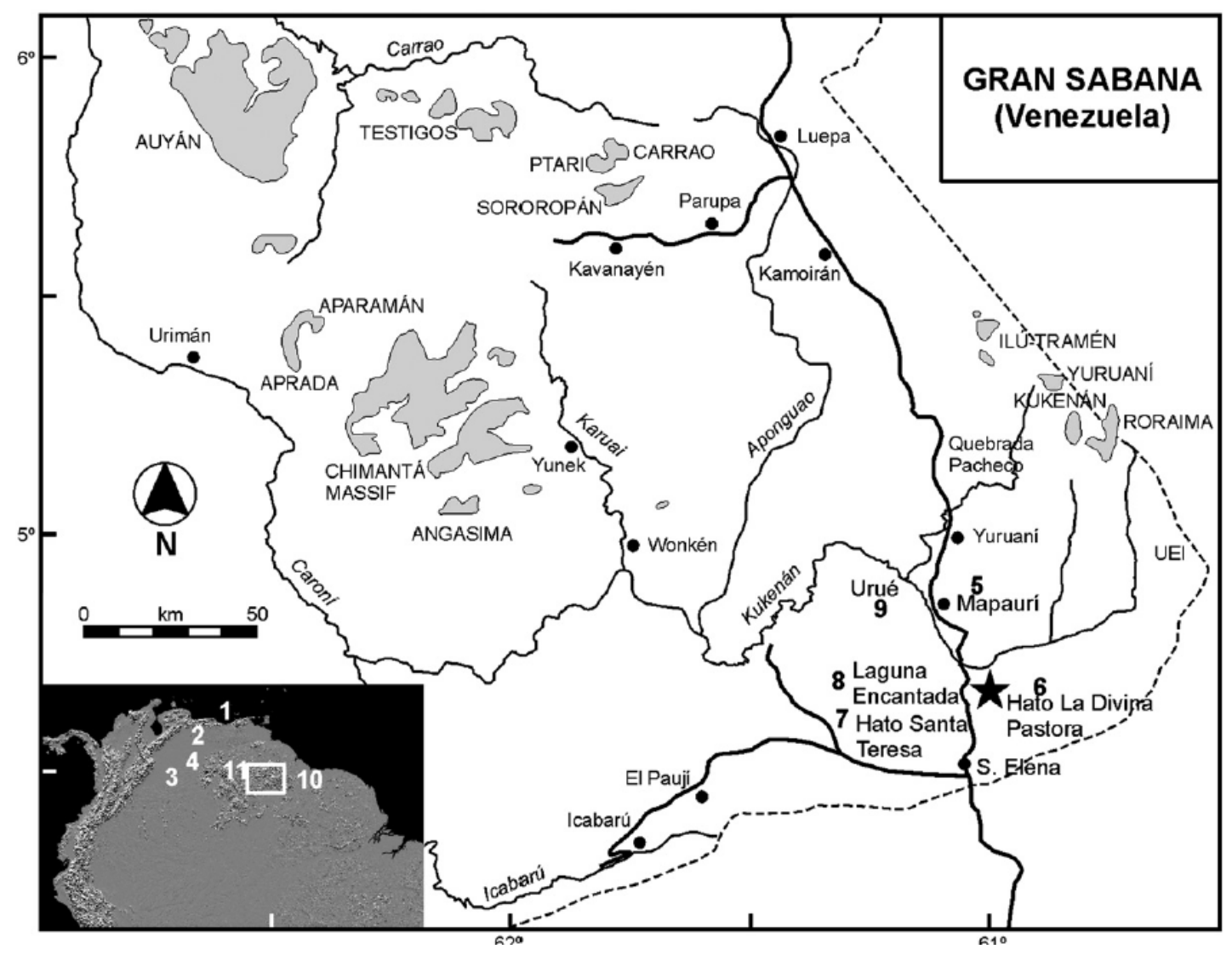

Figure 1. Location of the study area and its position within northern South America. (Radar image courtesy of NASA/JPL-Caltech). The coring site is indicated by a star. Numbers indicate the sites with paleoecological information mentioned in the text: 1 - Cariaco Basin (Venezuela); 2 - Lake Valencia (Venezuela); 3 - Colombian Llanos; 4 Orinoco savannas (Venezuela); 5 - Mapaurí (Gran Sabana); 6 - Divina Pastora (Gran Sabana); 7 — Santa Teresa (Gran Sabana); 8 - Lake Encantada; 9 -Urué (Gran Sabana); 10 -Rupununi savannas (Guyana); and 11 Canaima (Gran Sabana).

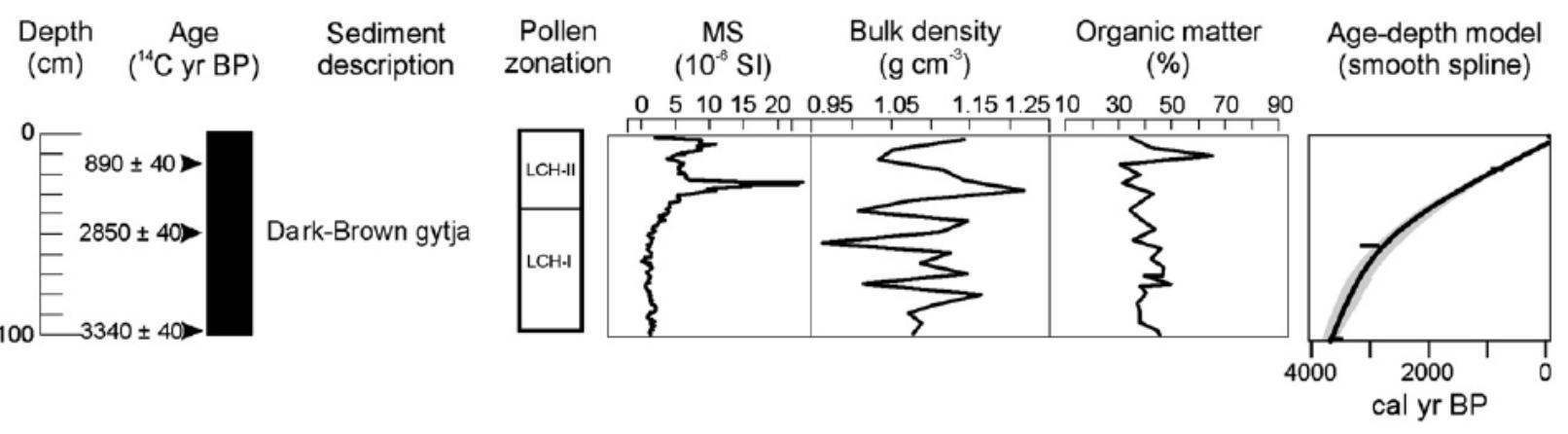

Figure 2. Core stratigraphy, with radiocarbon ages (in radiocarbon years, uncalibrated ages) and sediment description; pollen zones, physical parameters curves and age-depth model of the study section. MS: Magnetic susceptibility. 
Table 1

AMS radiocarbon dates used for the age-depth model for the whole record. Asterisks mark the dates included in the interval under study. The estimated ages have been extracted from the calibrated ages (WA: Weighed average).

\begin{tabular}{|c|c|c|c|c|c|c|}
\hline Laboratory & Sample & Depth (cm) & Sample material & Age (yr 14C BP) & Age (cal yr BP) $2 \sigma$ & $\begin{array}{l}\text { Age (cal yr BP) } \\
\text { estimation (WA) }\end{array}$ \\
\hline Beta-279600* & PATAM1_B07/3 & 13 & Pollen extract & $890 \pm 40$ & $731-915$ & 800 \\
\hline Beta-277185* & PATAM1_B07/11 & 51 & Pollen extract & $2850 \pm 40$ & 2855-3078 & 2730 \\
\hline Beta-277184* & PATAM1_B07/22 & 98 & Pollen extract & $3340 \pm 40$ & $3471-3643$ & 3660 \\
\hline UCl-43705 & PATAM1_B07/32 & 144 & Wood & $4080 \pm 40$ & $4497-4655$ & 4640 \\
\hline UCI-43706 & PATAM1_B07/49 & 212 & Wood & $6465 \pm 25$ & $7323-7403$ & 7380 \\
\hline Beta-277186 & PATAM1_B07/70 & 298 & Pollen extract & $9590 \pm 60$ & $10,738-11,164$ & 10,690 \\
\hline UCI-43537 & PATAM1_B07/87 & 362 & Wood & $9720 \pm 70$ & $11,063-11,251$ & 11,380 \\
\hline Beta-247284 & PATAM1_B07/93 & 392 & Wood & $10,440 \pm 40$ & $12,128-12,530$ & 12,340 \\
\hline UCI-43614 & PATAM1_B07/99 & 402 & Wood & $11,005 \pm 45$ & $12,699-13,078$ & 12,740 \\
\hline
\end{tabular}


PATAM1-B07

Anatyst: E Montoy

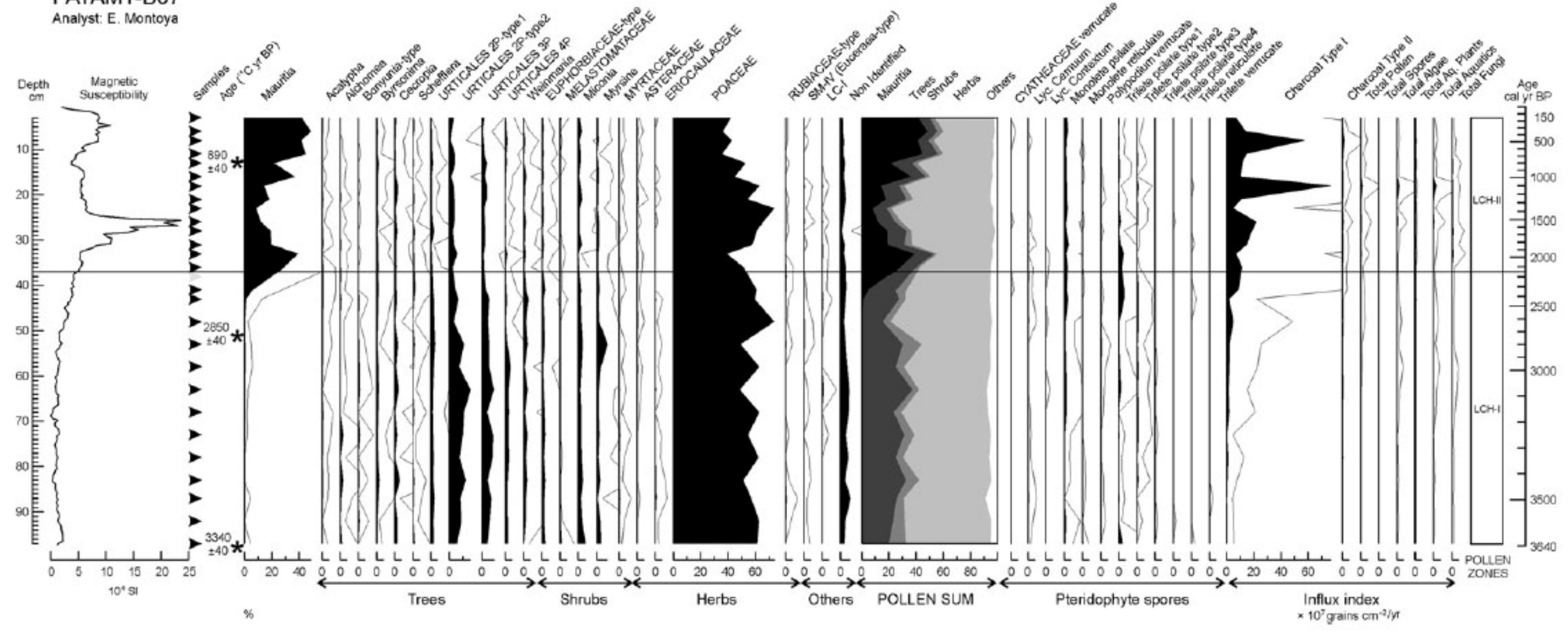

Figure 3. General pollen diagram expressed in percentages. Solid lines represent $\times 10$ exaggeration. Excluded sample $(38 \mathrm{~cm}$ depth) is marked in gray, Time scale has been done according to the age depth model obtained for the sequence

(Fig. 2) 


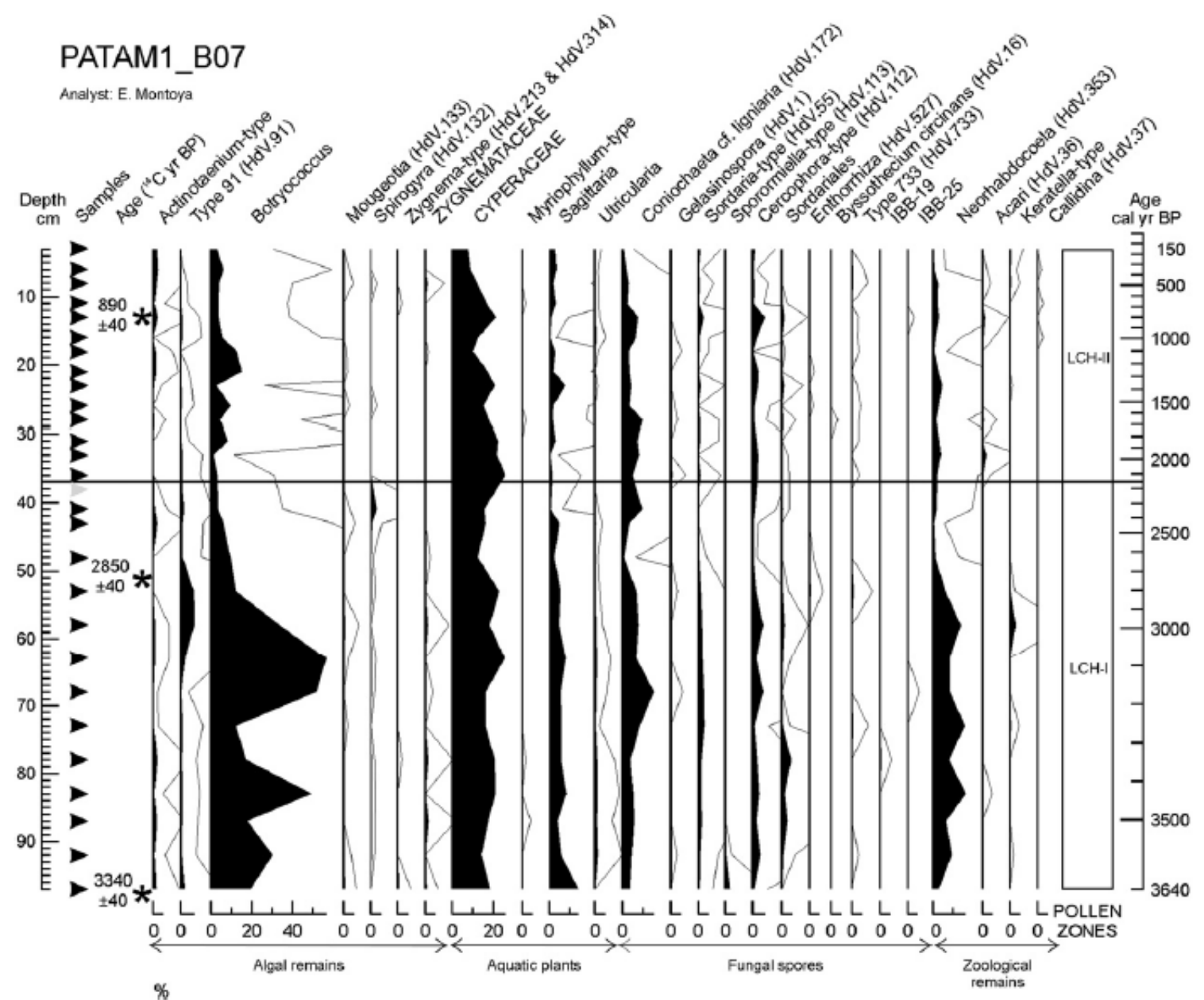

Figure 4. General non-pollen palynomorphs (extra pollen sum taxa) diagram expressed in percentages respect to pollen sum. Solid lines represent $\times 10$ exaggeration. HdV: Hugo de Vries Lab; IBB: Institut Botànic de Barcelona. Excluded sample (38 cm depth) is marked in gray. Time scale has been done according to the age depth model obtained for the sequence (Fig.2). 


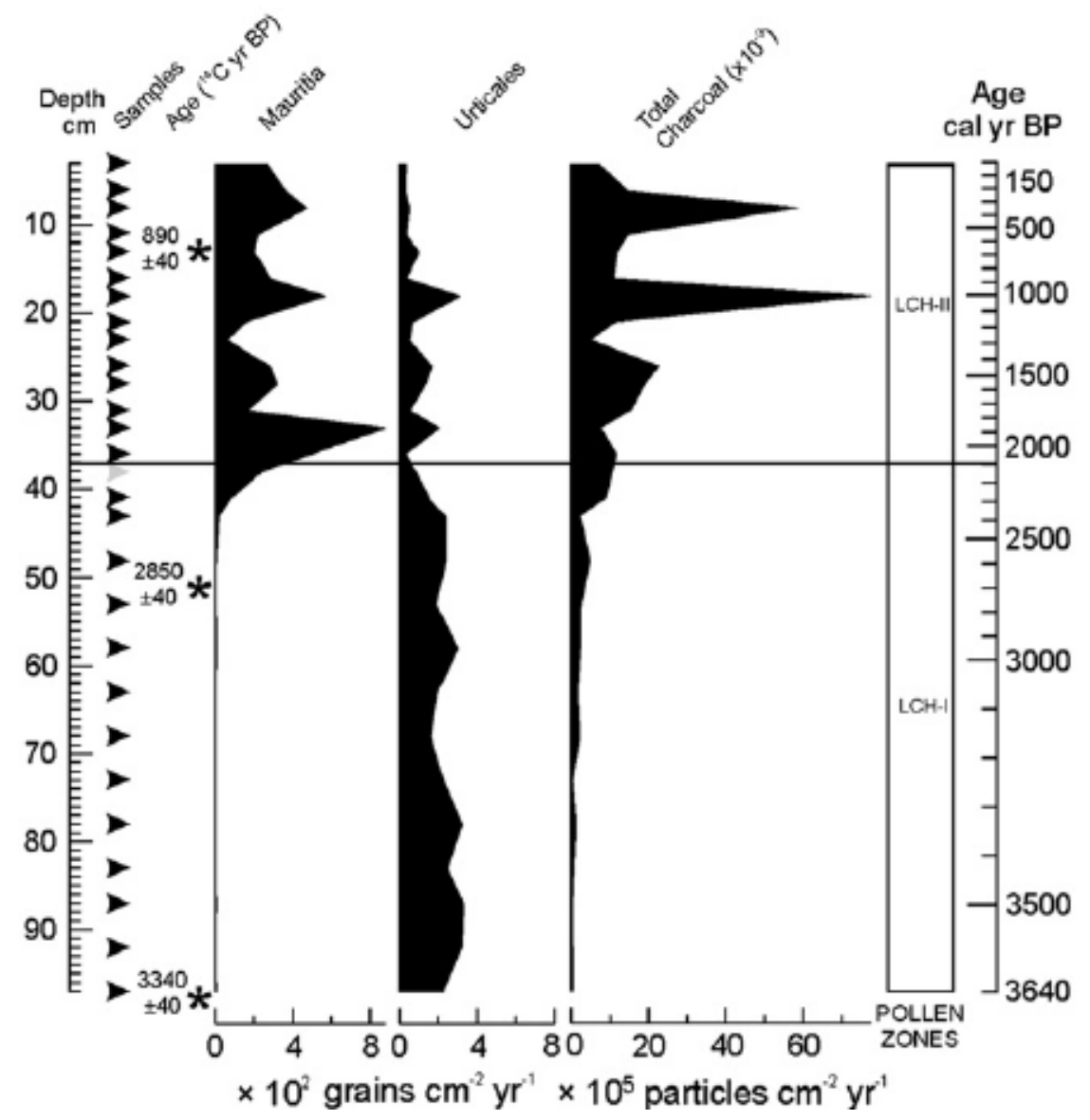

Figure 5. Influx index diagram of Mauritia pollen, Urticales pollen as indicative of forests following Gosling et al. (2009) and total charcoal particles. Excluded sample (38 cm depth) is marked in gray. Time scale has been done according to the age-depth model obtained for the sequence (Fig. 2).

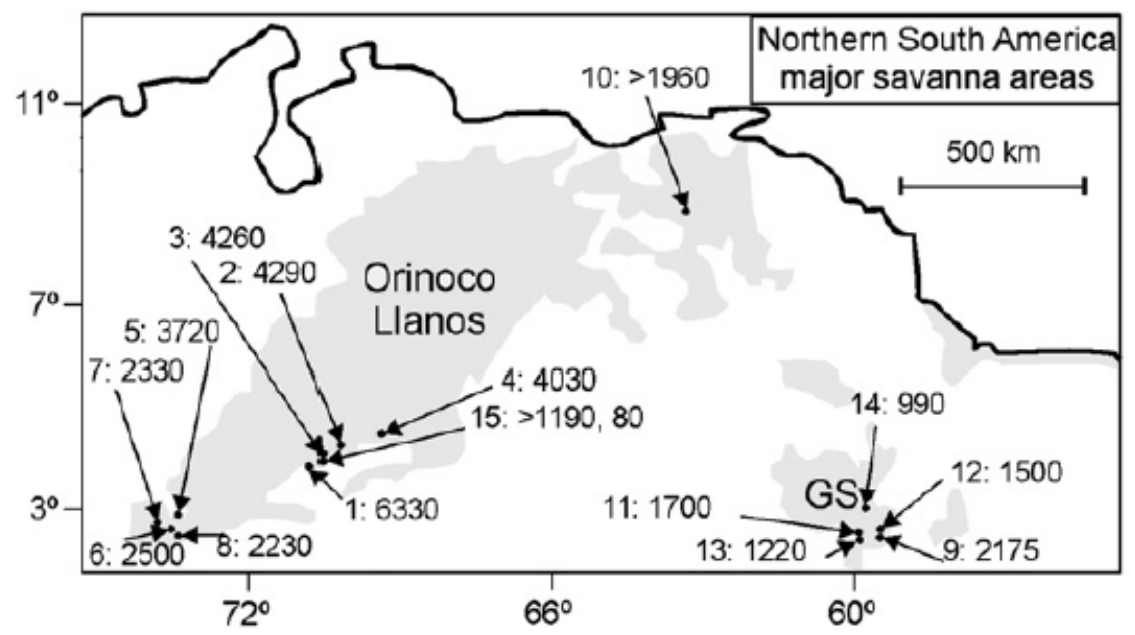

Figure 6. Location of sequences where morichal establishment has been reported in northern South American savannas. Map extracted from Behling and Hooghiemstra (2001) and Eva et al. (2004); present-day savanna areas are marked in gray. Numbers are referred to: (i) the sequences properly, they are ordered chronologically and showed at appendix; and (ii) the age (expressed in cal yr BP) of the morichal establishment. GS: Gran Sabina; N marks those localities where morichales were present at the beginning of the record, so the palm establishment must have occurred earlier. See appendix for all information related. 


\section{References}

Abbott, M.B., Stafford, T.W., 1996. Radiocarbon geochemistry of modern and ancient Arctic lake systems, Baffin Island, Canada. Quaternary Research 45, 300-311.

Behling, H., Hooghiemstra, H., 1998. Late Quaternary palaeoecology and palaeoclimatology from pollen records of the savannas of the Llanos Orientales in Colombia.Palaeogeography, Palaeoclimatology, Palaeoecology 139, 251-267.

Behling, H., Hooghiemstra, H., 1999. Environmental history of the Colombian savannas of the Llanos Orientales since the Last Glacial Maximum from lake records EI Pinal and Carimagua. Journal of Paleolimnology 21, 461-476.

Behling, H., Hooghiemstra, H., 2000. Holocene Amazon rainforest-savanna dynamics and climatic implications: high-resolution pollen record from Laguna Loma Linda in eastern Colombia. Journal of Quaternary Science 15, 687-695.

Behling, H., Hooghiemstra, H., 2001. Neotropical savanna environments in space and time: Late Quaternary interhemispheric comparisons. In: Markgraf, V. (Ed.), Interhemispheric Climate Linkages. Academic Press, San Diego, pp. 307-323.

Bennett, K.D., 1996. Determination of the number of zones in a biostratigraphical sequence. The New Phytologist 132, 155-170.

Berrío, J.C., Hooghiemstra, H., Behling, H., van der Borg, K., 2000. Late Holocene history of savanna gallery forest from Carimagua area, Colombia. Review of Palaeobotany and Palynology 111, 295-308.

Berrío, J.C., Hooghiemstra, H., Behling, H., Botero, P., van der Borg, K., 2002. Late-Quaternary savanna history of the Colombian Llanos Orientales from Lagunas Chenevo and Mozambique: a transect synthesis. The Holocene 12, 35-48.

Blaauw, M., 2010. Methods and code for "classical" age-modelling of radiocarbon sequences. Quaternary Geochronology 5, 512-518.

Bradbury, J.P., Leyden, B., Salgado-Labouriau,M.L., Lewis,W.M., Schubert, C., Benford,M.W., Frey, D.G., Whitehead, D.R., Weibezahn, F.H., 1981. Late Quaternary environmental history of Lake Valencia, Venezuela. Science 214, 1299-1305.

Briceño, H.O., Schubert, C., 1990. Geomorphology of the Gran Sabana, Guayana Shield. Geomorphology 3, 125-141.

Bush, M.B., Silman, M.R., de Toledo, M.B., Listopad, C., Gosling, W.D., Williams, C., De Oliveira, P.E., Krisel, C., 2007. Holocene fire and occupation in Amazonia: records from two lake districts. Philosophical Transactions of the Royal Society B: Biological Sciences 362, 209-218.

Colinvaux, P.A., De Oliveira, P.E., Moreno, J.E., 1999. Amazon Pollen Manual and Atlas. Harwood Academic Publishers, Amsterdam.

Colson, A.B., 1985. Routes of knowledge, an aspect of regional integration in the circum-Roraima area of the Guayana highlands. Antropológica 63 (64), 103-149.

Curtis, J.H., Brenner, M., Hodell, D.A., 1999. Climate change in the lake Valencia basin, Venezuela, 12600 yr BP to present. The Holocene 9, 609-619.

Dean, W.E., 1974. Determination of carbonate and organic matter in calcareous sediments and sedimentary rocks by loss on ignition: comparison with other methods. Journal of Sedimentary Petrology 44, 242-248.

Dezzeo, N., Chacón, N., Sanoja, E., Picón, G., 2004. Changes in soil properties and vegetation characteristics along a forest-savanna gradient in southern Venezuela. Forest Ecology and Management 200, 183-193.

Eden, M.J., 1974. Paleoclimatic influences and the development of savanna in southern Venezuela. Journal of Biogeography 1, 95-109.

Eva, H.D., Belward, A.S., de Miranda, E., di Bella, C.M., Gond, V., Huber, O., Jones, S., Sgrenzaroli, M., Fritz, S., 2004. A land cover map of SouthAmerica. Global Ecology and Biogeography 10, 731744.

Fölster, H., 1986. Forest-savanna dynamics and desertification processes in the Gran Sabana. Interciencia 11, 311-316.

Fölster, H., Dezzeo, N., Priess, J.A., 2001. Soil-vegetation relationship in base-deficient premontane moist forest-savanna mosaics of the Venezuelan Guayana. Geoderma 104, 95-113.

Gassón, R.A., 2002. Orinoquia: the archaeology of the Orinoco river basin. Journal of World Prehistory 16, 237-311.

Gomez-Beloz, A., 2002. Plant use knowledge of the Winikina Warao: the case for questionnaires in ethnobotany. Economic Botany 56, 231-241.

Gosling, W.D., Mayle, F.E., Tate, N.J., Killeen, T.J., 2009. Differentiation between Neotropical rainforest, dry forest, and savannah ecosystems by their modern pollen spectra and implications for the fossil pollen record. Review of Palaeobotany and Palynology 153, 70-85. 
Haug, G.H., Hughen, K.A., Sigman, D.M., Peterson, L.C., Röhl, U., 2001. Southwardmigration of the Intertropical Convergence Zone through theHolocene. Science 293, 1304-1308.

Heckenberger, M., Neves, E.G., 2009. Amazonian archaeology. Annual Review of Anthropology 38, 251266.

Henderson, A., Galeano, G., Bernal, R., 1995. Field Guide to the Palms of the Americas. Princeton University Press, New Jersey.

Hernández, L., 1999. Fisionomía y estructura de bosques submesotérmicos y mesotérmicos. Ecología de la altiplanicie de la Gran Sabana (Guayana Venezolana) II. Estructura, diversidad, crecimiento y adaptación en bosques de las subcuencas de los ríos Yuruaní y Alto Kukenán. : In: Hernández, L. (Ed.), Scientia Guayanae, Vol. 9. Ediciones Tamandúa, Caracas, pp. 5-34.

Herrera, L.F., Urrego, L.E., 1996. Atlas de polen de plantas útiles y cultivadas de la Amazonia colombiana. Tropenbos Colombia, Colombia.

Hooghiemstra, H., 1984. Vegetational and climatic history of the High Plain of Bogotá, Colombia: a continuous record of the last 3.5 million years. In: van der Hammen, T. (Ed.), The Quaternary of Colombia, Vol. 10. J. Cramer, Amsterdam.

Huber, O., 1986. La vegetación de la cuenca del Río Caroní. Interciencia 11, 301-310.

Huber, O., 1987. Neotropical savannas: their flora and vegetation. Trends in Ecology \& Evolution 2, 67-71.

Huber, O., 1989. Shrublands of the Venezuelan Guayana. In: Holm-Nielsen, L.B., Nielsen, I.C., Balslev, H. (Eds.), Tropical Forests. Academic Press, London, pp. 271-285.

Huber, O., 1994. La vegetación: Arbustales. Ecología de la Altiplanicie de la Gran Sabana (Guayana Venezolana) I. Investigaciones sobre la dinámica bosque-sabana en el sector SE: subcuencas de los ríos Yuruaní, Arabopó y Alto Kukenán. : In: Dezzeo, N. (Ed.), Scientia Guayanae, Vol. 4. Ediciones Tamandúa, Caracas, pp. 95-106.

Huber, O., 1995a. Geographical and physical features. Flora of the Venezuelan Guayana. In: Steyermark, J.A., Berry, P.E., Holst, B.K. (Eds.), Introduction, Vol. 1. Missouri Botanical Garden Press, Missouri, pp. 1-62.

Huber, O., 1995b. Vegetation. Flora of the Venezuelan Guayana. : In: Steyermark, J.A., Berry, P.E., Holst, B.K. (Eds.), Introduction, Vol. 1. Missouri Botanical Garden Press, Missouri, pp. 97-160.

Huber, O., 2006. Herbaceous ecosystems on the Guayana Shield, a regional overview. Journal of Biogeography 33, 464-475.

Huber, O., Febres, G., 2000. Guía ecológica de la Gran Sabana. The Nature Conservancy, Caracas. Kingsbury, N.D., 1999. Increasing pressure on decreasing resources: a case study of Pemón Amerindian shfting cultivation in the Gran Sabana, Venezuela. PhD Thesis, Toronto, Canada.

Kingsbury, N.D., 2001. Impacts of land use and cultural change in a fragile environment: indigenous acculturation and deforestation in Kavanayén, Gran Sabana, Venezuela. Interciencia 26, 327336.

Leal,A., Rull,V., Bilbao, B., 2002. Cambios climáticos y de vegetación durante el Holoceno en los Llanos Orientales de Venezuela: implicaciones sobre la biogeografía de Mauritia flexuosa L.f. (Arecaceae). VIII Congreso Latinoamericano de Botánica, Cartagena (Colombia).

Leal, A., Rull, V., Bilbao, B., 2003. Cambios climáticos durante el Holoceno en los Llanos de Venezuela: implicaciones sobre la biogeografía de Mauritia flexuosa L.f. (Arecaceae). XV Congreso Venezolano de Botánica, Mérida (Venezuela).

Leyden, B.W., 1985. Late Quaternary aridity and Holocene moisture fluctuations in the Lake Valencia Basin, Venezuela. Ecology 66, 1279-1295.

Marchant, R., Almeida, L., Behling, H., Berrío, J.C., Bush, M., Cleef, A., Duivenvoorden, J., Kappelle, M., De Oliveira, P., Teixeira, A., Lozano, S., Hooghiemstra, H., Ledru, M.P., Ludlow-Wiechers, B.,Markgraf, V.,Mancini, V., Páez,M., Prieto, A., Rangel, O., Salgado- Labouriau,M.L., 2002. Distribution and ecology of parent taxa of pollen lodged within the LatinAmerican PollenDatabase.Reviewof Palaeobotany andPalynology 121, 1-75.

Marchant, R., Hooghiemstra, H., 2004. Rapid environmental change in African and South American tropics around 4000 years before present: a review. Earth-Science Reviews 66, 217-260.

Medina, J., Croes, G., Piña, I., 2004. Evaluación de políticas públicas del pueblo Pemón: componentes socioeconómico y ambiental. D.d.A.I. Ministerio de Educación y Deportes. The Nature Conservancy, Caracas.

Montoya, E., Rull, V., Nogué, S., Díaz, W.A., 2009. Paleoecología del Holoceno en la Gran Sabana, SE Venezuela: Análisis preliminar de polen y microcarbones en la Laguna Encantada. Collectanea Botanica 28, 75-89.

Montoya, E., Rull, V., van Geel, B., 2010. Non-pollen palynomorphs from surface sediments along an altitudinal transect of the Venezuelan Andes. Palaeogeography, Palaeoclimatology, Palaeoecology 297, 169-183.

Montoya, E., Rull, V., Stansell, N.D., Bird, B.W., Nogué, S., Vegas-Vilarrúbia, T., Abbott, M.B., Díaz, W.A., 2011. Vegetation changes in the Neotropical Gran Sabana (Venezuela) around the Younger Dryas Chron. Journal of Quaternary Science 26, 207-218.

Polissar, P.J., Abbott, M.B., Wolfe, A.P., Bezada, M., Rull, V., Bradley, R.S., 2006. Solar modulation of 
Little Ice Age climate in the tropical Andes. Proceedings of the National Academy of Sciences 103, 8937-8942.

Ponce,M.E., 2002. Patrones de caída de frutos enMauritia flexuosa L.F. y fauna involucrada en los procesos de remoción de semillas. Acta Botanica Venezuelica 25, 119-142.

Ponce, M.E., Brandin, J., Ponce, M.A., González, V., 1999. Germinación y establecimiento de plántulas de Mauritia flexuosa L.f. (Arecaceae) en los Llanos Sur-Orientales del Estado Guárico, Venezuela. Acta Botanica Venezuelica 22, 167-183.

Rodríguez, I., 2004. Conocimiento indígena vs científico: el conflicto por el uso del fuego en el Parque Nacional de Canaima, Venezuela. Interciencia 29, 121-129.

Rodríguez, I., 2007. Pemon perspectives of fire management in Canaima National Park, Southeastern Venezuela. Human Ecology 35, 331-343.

Roubik, D.W., Moreno, J.E., 1991. Pollen and Spores of Barro Colorado Island. Missouri Botanical Garden, Missouri.

Rostain, S., 2008. The archaeology of the Guianas: an overview. In: Silverman, H., Isbell,W.H. (Eds.), Handbook of South American Archaeology. Springer, New York, pp. 279-302.

Rull, V., 1987. A note on pollen counting in palaeoecology. Pollen et Spores 29, 471-480.

Rull, V., 1992. Successional patterns of the Gran Sabana (southeastern Venezuela) vegetation during the last 5000 years, and its responses to climatic fluctuations and fire. Journal of Biogeography 19, 329-338.

Rull, V., 1998a. Contribución a la morfología polínica de las Urticales de los Andes venezolanos. Acta Botanica Venezuelica 21, 43-73.

Rull, V., 1998b. Biogeographical and evolutionary considerations on Mauritia (Arecaceae), based on palynological evidence. Review of Palaeobotany and Palynology 100, 109-122.

Rull, V., 1999. A palynological record of a secondary succession after fire in the Gran Sabana, Venezuela. Journal of Quaternary Science 14, 137-152.

Rull, V., 2003. An illustrated key for the identification of pollen from Pantepui and the Gran Sabana (eastern Venezuelan Guayana). Palynology 27, 95-129.

Rull, V., 2007. Holocene global warming and the origin of the Neotropical Gran Sabana in the Venezuelan Guayana. Journal of Biogeography 34, 279-288.

Rull, V., Abbott, M.B., Vegas-Vilarrúbia, T., Bezada, M., Montoya, E., Nogué, S., González, C., 2010a. Paleoenvironmental trends in Venezuela during the last glacial cycle. In: Sánchez-Villagra, M.R., Aguilera, O., Carlini, A. (Eds.), Urumaco and Venezuelan Palaeontology - The Fossil Record of the Northern Neotropics. Indiana University Press, Indiana, pp. 52-83.

Rull, V., Stansell, N.D., Montoya, E., Bezada, M., Abbott, M.B., 2010b. Palynological signal of the Younger Dryas in the tropical Venezuelan Andes. Quaternary Science Reviews 29, 3045-3056.

Saldarriaga, J.G., Webs, D.C., 1986. Holcelene fires in the Northern Amamzon basin. Quaternary Research 26, 358-366.

Thomas, D.J., 1982. Order Without Government: The Society of the Pemons Indians of Venezuela. University of Illinois Press, Illinois.

Tryon, A.F., Lugardon, B., 1991. Spores of the Pteridophyta. Surface, Wall Structure, and Diversity Based on Electron Microscope Studies. Springer-Verlag, New York.

Wille, M., Hooghiemstra, H., van Geel, B., Behling, H., de Jong, A., van der Borg, K., 2003.

Submillenium-scale migrations of the rainforest-savanna boundary in Colombia: C-14 wiggle-matching and pollen analysis of core Las Margaritas. Palaeogeography, Palaeoclimatology, Palaeoecology 193, 201-223.

Wright, H.E., Mann, D.H., Glaser, P.H., 1984. Piston corers for peat and lake sediments. Ecology 65, 657659.

Wymstra, T.A., van der Hammen, T., 1966. Palynological data on the history of tropical savannas in northern South America. Leidse Geologische Mededelingen 38, 71-90 